\title{
Pengolahan Slurry Sampah melalui Microbial Fuel Cells di Pasar Giwangan Yogyakarta
}

\author{
Ilham Mufandi ${ }^{\text {a,* }}$, Isti Nur Azizah ${ }^{\text {b }}$, Arpan Efendi ${ }^{\text {b }}$, Zahrul Mufrodi ${ }^{\text {b }}$ \\ ${ }^{a}$ Department of Mechanical Engineering, Faculty of Engineering, Khon Kaen University, Thailand \\ ${ }^{b}$ Program Studi Teknik Kimia, Fakultas Teknologi Industri, Universitas Ahmad Dahlan, Yogyakarta \\ *ilhammufandi1805@gmail.com
}

ARTICLE INFO

Article history

Received November 21, 2018

Revised Desember 11, 2018

Accepted Desember 11, 2018

Keywords

Electrical Energy

Microbial Fuel Cells (MFCs)

Vegetable waste

\begin{abstract}
The vegetable waste is one of the biomass types that it can produce electrical energy. This article focused on electrical production of vegetable waste using microbial fuel cells (MFCS) MFCs is the primary type of the bioelectrochemical system (BECs) that to replaces the biomass to electrical energy spontaneously by activity metabolism of the microorganism. The objectives of this work were to investigate the process of electrical production from Chinese cabbage and the combination of the materials to produce the electrical energy. The experiment was carried out in a laboratory-sall such as mini reactor MFCs, Chinese cabbage as the material of vegetable waste and EM4 as the fermentation. Sample combination was consist of two parts that the first part was used $1 \mathrm{~kg}$ Chinese cabbage, 2 liter water and $20 \mathrm{ml}$ EM4. The second part was used $2 \mathrm{~kg}$ Chinese cabbage, 1 liter water and $20 \mathrm{ml}$ EM4. The result showed that the electrical voltage in part 1 at $0.362 \mathrm{~V}$ and $\mathrm{pH}$ at 6 was lower than the electrical voltage in part 2 at $0.724 \mathrm{~V}$ and $\mathrm{pH}$ at 7 . Declining electric energy is influenced by $\mathrm{pH}$ as microorganisms living place and the formation process of attached media at the electrode.
\end{abstract}

This is an open access article under the CC-BY-SA license.

\section{Pendahuluan}

Pemerintah Indonesia melakukan berbagai alternatif untuk meningkatkan perekonomian rakyat, salah satu cara yang produktif dengan melakukan pembangunan kawasan komersial yaitu pasar tradisional. Menurut Peraturan perdagangan RI Nomor: 70/M-DAG/PER/12/2013 tentang pedoman penataan pasar tradisional mengatakan bahwa pasar tradisional adalah pasar yang dibangun dan dikelola oleh pemerintah daerah, swasta, badan usaha milik negara dan badan usaha milik daerah kerjasama dengan swasta dan tempat usaha berupa toko, kios, los dan tenda yang dimiliki/ dikelola oleh pedagang kecil, menengah dan swadaya masyarakat atau koperasi dengan usaha skala kecil, modal kecil dengan proses jual beli barang dagangan melalui tawar meneawar.

Indonesia memiliki lebih dari 1000 pasar tradisional yang beroperasi untuk meningkatkan perekonomia rakyat. Di D.I. Yogyakarta terdapat 32 pasar tradisional. Berdasarkan Peraturan Walikota Yogyakarta Nomor 13 tahun 2010 mengatakan bahwa aktivitas pasar tradisonal ini memiliki keunggulan dan kekurangan yaitu secara umum keunggulan pasar tradisional ini dapat meningkatkan perekonomian rakyat dengan aktivitas jual beli, namun di sisi lain aktivitas pasar memiliki kekurangan yaitu secara tidak langsung menghasilkan sampah organik maupun anorganik dari aktivitas pasar tersebut. Sampah pasar dapat berupa sisa sayuran, buah-buahan, dan bahan makanan lain yang dapat membusuk dan menimbulkan bau yang tidak sedap.

Sampah sisa sayuran sangat mudah ditemukan di pasar-pasar tradisional. Menurut data dari BLH Kota Yogyakarta, 2016 mengatakan bahwa kapasitas sampah di Yogyakarta menyumbang sebanyak 4.436.373 ton. Sampah yang dihasilkan dari pasar tradisional sebanyak 2 truk/hari. Setiap truk 
sampah dapat mengankut 8-9 $\mathrm{m}^{3}$. Berdasarkan penelitian Rahayu [1] mengatakan bahwa timbulan sampah di Pasar Segiri Samarinda sebanyak $5,94 \mathrm{~m}^{3} /$ hari dengan potensi terbesar berasal dari sampah organik yang mudah terurai yaitu 78,26\%. Berdasarkan Djafar [2] sudah melakukan penelitian di Pasar Induk Ciringin Bandung bahwa timbulan sampah sebesar 1,64 kg/m² atau 7,44 liter $/ \mathrm{m}^{2} /$ hari. Pemanfaatan dari adanya sampah organik di pasar-pasar tradisonal lebih banyak kepada produk olahan kompos. Namun, pengolahan sampah dengan teknik kompos menimbulkan pencemaran lingkungan seperti meningkatnya gas ammonia [3]. Teknik pengomposan dapat meningkatan presentasi ammonia. Proses pengomposan sampah dapat menimbulkan dampak ke lingkungan seperti asidifikasi (pengasaman) dan eutrofikasi. Peningkatan pengasaman (asidifikasi) juga dihasilkan pada lokasi pembuangan akhir. Pengomposan juga merupakan penyumbang terbesar dari proses asidifikasi, seperti timbulnya ammonia [4].

Penyebab terjadinya asidifikasi di lingkungan adalah dari ammonia yang terlepas ke udara. Ammonia yang terlepas ke udara ini dikarenakan adanya proses penguraian oleh mikroorganisme pada proses pengomposan. Berdasarkan hal tersebut, perlu dikaji lebih lanjut potensi dan peluang pengolahan sampah pasar terutama sampah sayur menjadi produk lain. Salah satu potensi penting yang dapat dikaji adalah potensi sampah sayur dalam produksi energi [5].

Sejalan dengan hal tersebut, Badan Pengkajian dan Penerapan Teknologi (2010) menyatakan bahwa 50\% konsumsi energi nasional Indonesia selama ini berasal dari minyak bumi. Hal ini menunjukkan bahwa bangsa Indonesia masih sangat tergantung pada sumber energi tak terbarukan tersebut. Masalah tersebut harus segera dicari solusinya karena cepat atau lambat sumber energi fosil akan habis. Keadaan ini menyebabkan negara-negara di dunia termasuk Indonesia rentan terhadap resiko krisis energi. Melihat kondisi yang demikian, peluang untuk mengembangkan energi terbarukan masih memiliki posisi yang strategis di Indonesia.

Salah satu energi alternatif terbarukan ini adalah Microbial Fuel Cells (MFCs). MFCs merupakan jenis utama dari bioelectrochemical system (BECs) yang mengonversi biomassa secara spontan menjadi listrik melalui aktivitas metabolisme mikroorganisme [6]. MFCs dianggap sebagai teknologi berkelanjutan untuk menghadapi peningkatan kebutuhan energi. MFCs telah banyak digunakan untuk mengolah air limbah seperti limbah domestik [7], limbah makanan [8], limbah bir [9],[10], limbah wiski [11], limbah industri gula [12], limbah industri kertas [13], limbah penggilingan padi, limbah peternakan babi dan limbah fenolik [14].

Tujuan dari penelitian ini adalah untuk memproduksi listrik dari limbah sayur melalui teknologi microbial cell. Sampah sayur sebagai bahan utama penelitian didapat di Pasar Giwangan Yogyakarata. Ada tiga proses dalam penelitian ini yaitu teknik graping, pembuatan slurry dan pengujuan slurry menggunakan reaktor mini MFCs yang didesain skala laboratorium.

\section{Metodologi Penelitian}

\subsection{Bahan penelitian}

Bahan baku pada penelitian ini terdiri dari limbah sayur yang tersedia di Pasar Giwangan, air, dan Effective Microorganisme (EM4). Limbah sayur di potong menggunakan alat potong pisau yang mana untuk aktivasi bakteri menggunkan EM4. Gambar 1. Desain reaktor mini MFCs terdiri dari katoda dan anoda, voltase meter, $\mathrm{pH}$ meter, storage dan termometer.

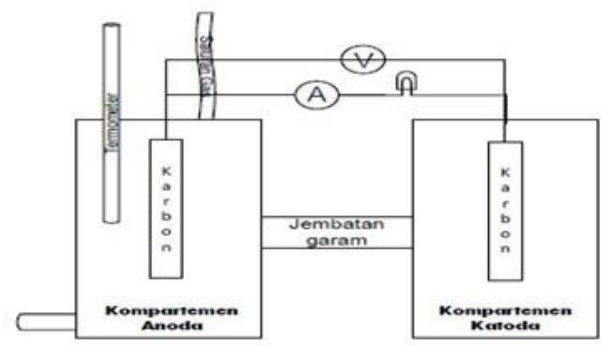

Gambar 1. Desain Reaktor MFCs dengan Substrat Sampah Sayur Pasar Fase Slurry 


\subsection{Metode Penelitian}

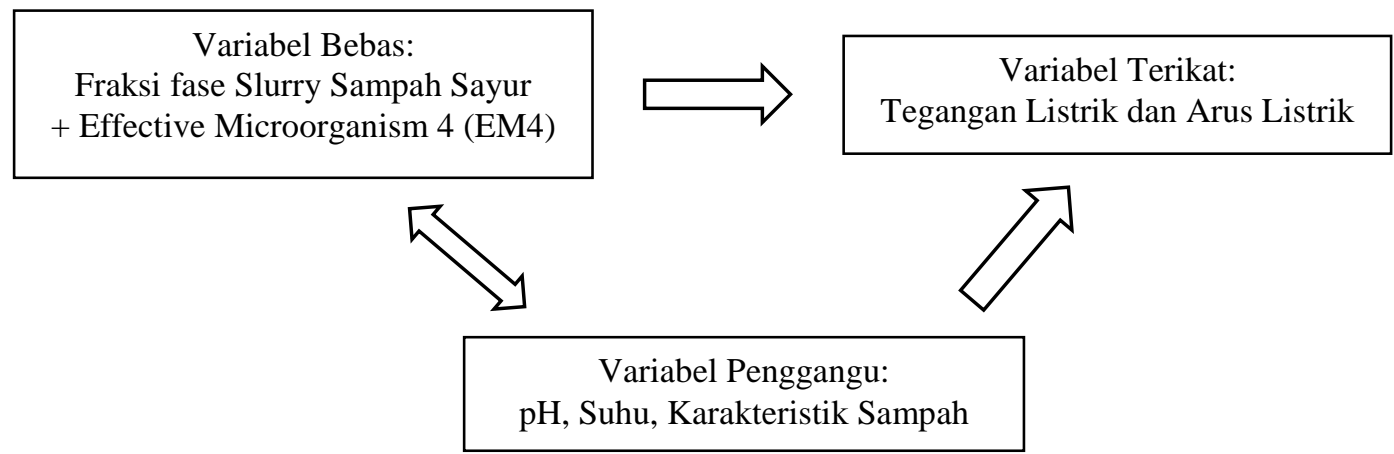

Gambar 2. Kerangka Konsep Penelitian

\subsubsection{Variabel Penelitian}

Variabel adalah karakteristik subyek penelitian yang berubah dari satu subyek ke subyek lainnya [15]. Varibel bebas (independen) adalah variabel yang nilainya menentukan variabel lain [16]. Variabel bebas dalam penelitian ini adalah Fraksi fase Slurry Sampah Sayur + EM4. Sedangkan yang dimaksud variabel terikat (dependen) adalah variabel yang nilainya ditentukan oleh variabel lain [16]. Variabel terikat dalam penelitian ini adalah tegangan dan arus listrik.

Variabel pengganggu atau perancu (confounding) merupakan variabel yang berhubungan dengan variabel bebas dan terikat, tetapi bukan merupakan variabel antara [15]. Variabel Perancu atau Pengganggu (confounding) dalam penelitian ini adalah $\mathrm{pH}$, suhu, karakteristik sampah, dan ukuran partikel.

\subsubsection{Pembuatan Slurry}

Penelitian ini merupakan penelitian yang menggunakan skala laboratorium, yaitu dengan membuat miniatur sistem yang dioperasikan untuk mendapatkan data dengan menggunakan reaktor MFCs. Sampel sampah yang digunakan adalah sampah sayur pasar yang diperoleh dari Pasar Giwangan, Kota Yogyakarta yang diambil dengan teknik grab sampling sampah artifisialnya dalam bentuk fase slurry. Kerangka konsep penelitian tercantum dalam gambar 2.

Tabel 1. Kandungan Karbohidrat, Kadar Air, dan Antioksidan.

\begin{tabular}{clcc}
\hline No. & Kriteria & Perbandingan 1 & Perbandingan 2 \\
\hline 1. & Sampah sayur $(\mathrm{kg})$ & 1 & 2 \\
\hline 2. & Air $(\mathrm{L})$ & 2 & 1 \\
\hline 3. & EM4 $(\mathrm{ml})$ & 20 & 20
\end{tabular}

\section{Hasil dan Pembahasan}

\subsection{Pengaruh jumlah slurry dengan produksi listrik}

Sampling sampah sayur diambil dari Pasar Giwangan Yogyakarta. Pemilihan sampah sayur konsentrasi kadar airnya berada kisaran 33,4-66,5\%. Jenis sampah sayur yang banyak terdapat di Pasar Giwangan yaitu kubis, labu, sawi, sawi putih, wortel, cabe, dan tomat dilihat pada Tabel 1.

Tabel 2. Komposisi Sampah Sayur Pasar Hasil Sampling

\begin{tabular}{cccc}
\hline No. & Jenis Sayur & Massa ( Kg.1 ) & Presentase (\%) \\
\hline $\mathbf{1 .}$ & Kubis & 4 & 50 \\
\hline $\mathbf{2 .}$ & Labu Siam & 2 & 25 \\
\hline $\mathbf{3 .}$ & Sawi & 0,8 & 10 \\
\hline $\mathbf{4 .}$ & Sawi Putih & 0,7 & 8,8 \\
\hline $\mathbf{5 .}$ & Wortel & 0,3 & 3,8 \\
\hline $\mathbf{6 .}$ & Cabe & 0,1 & 1,3 \\
\hline $\mathbf{7 .}$ & Tomat & 0,1 & 1,3
\end{tabular}


Dari sampel sampah sayur tersebut dibuat fase slurry sampah sayur dengan komposisi persentase jenis sayur. Fase slurry ini digunakan sebagai substrat pada kompartemen anode. Mikroorganisme yang berperan pada reaktor MFCs dapat berasal dari sampah sayur pasar maupun dari air yang digunakan sebagai campuran bahan untuk membentuk slurry sampah sayur. Mikroorganisme melekat pada anoda pada kondisi anaerobik. Selanjutnya, akan terjadi proses degradasi sampah sayur sehingga diperoleh karbondioksida, proton, serta elektron [17]. Slurry dapat diperoleh dari proses sedimentasi. Sedimentasi adalah salah satu operasi pemisahan campuran padatan dan cairan (slurry) menjadi cairan beningan dan sludge (slurry yang lebih pekat konsentrasinya) [17].

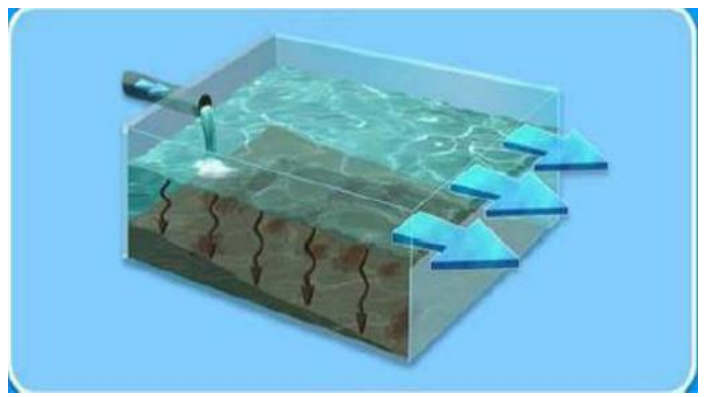

Gambar 3. Proses Sedimentasi Kontinyu

Dalam penelitian ini, proses sedimentasi yang cocok untuk digunakan adalah dengan cara atau metode Batch. Cara ini cocok dilakukan untuk skala laboratorium, karena sedimentasi batch paling mudah dilakukan, pengamatan penurunan ketinggian mudah. Mekanisme sedimentasi batch pada suatu silinder/ tabung bisa dilihat pada gambar berikut:

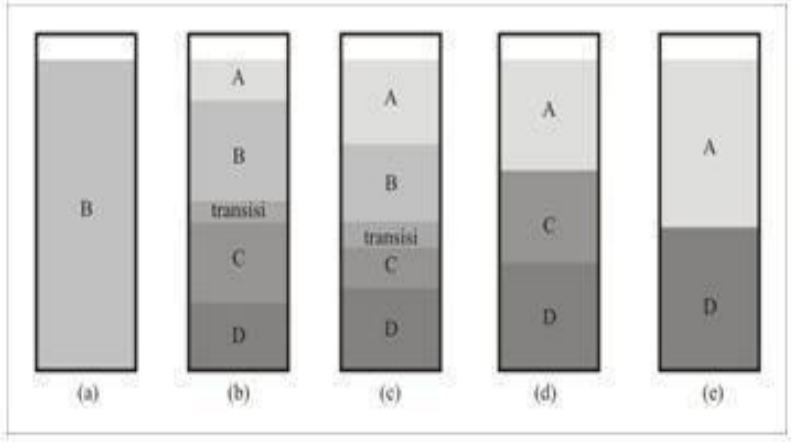

Gambar 4. Mekanisme Sedimentasi Batch

Keterangan :

$\mathrm{A}=$ cairan bening

$\mathrm{B}=$ zona konsentrasi seragam
$\mathrm{C}=$ zona ukuran butir tidak seragam

$\mathrm{D}=$ zona partikel padat terendapkan

Gambar di atas menunjukkan slurry awal yang memiliki konsentrasi seragam dengan partikel padatan yang seragam di dalam tabung (zona B). Partikel mulai mengendap dan diasumsikan mencapai kecepatan maksimum dengan cepat. Zona D yang terbentuk terdiri dari partikel lebih berat sehingga lebih cepat mengendap. Pada zona transisi, fluida mengalir ke atas karena tekanan dari zona $\mathrm{D}$. Zona $\mathrm{C}$ adalah daerah dengan distribusi ukuran yang berbeda-beda dan konsentrasi tidak seragam. Zona B adalah daerah konsentrasi seragam, dengan komsentrasi dan distribusi sama dengan keadaan awal. Di atas zona B, adalah zona A yang merupakan cairan bening [18].

Selama sedimentasi berlangsung, tinggi masing-masing zona berubah (gambar 2 b, c, d). Zona A dan D bertambah, sedang zona B berkurang. Akhirnya zona B, C dan transisi hilang, semua padatan berada di zona D. Saat ini disebut critical settling point, yaitu saat terbentuknya batas tunggal antara cairan bening dan endapan . Proses selanjutnya aalah degradasi sampah sayur tersebut termasuk reaksi oksidasi. Proses terbentuknya listrik yaitu dari proses pengubahan senyawa selulosa melalui proses hidrolisis, fermentasi, dan elektrogenesis. Hasil dekomposisi bahan organik kompleks yang ada di dalam sampah sayur dapat digunakan sebagai sumber energi untuk tahap berikutnya [5]. Hasil 
penelitian menunjukkan adanya voltase dan arus listrik yang mengalir pada masing-masing reaktor. Perubahan voltase pada masing-masing reaktor dapat dilihat pada Gambar 5 berikut:

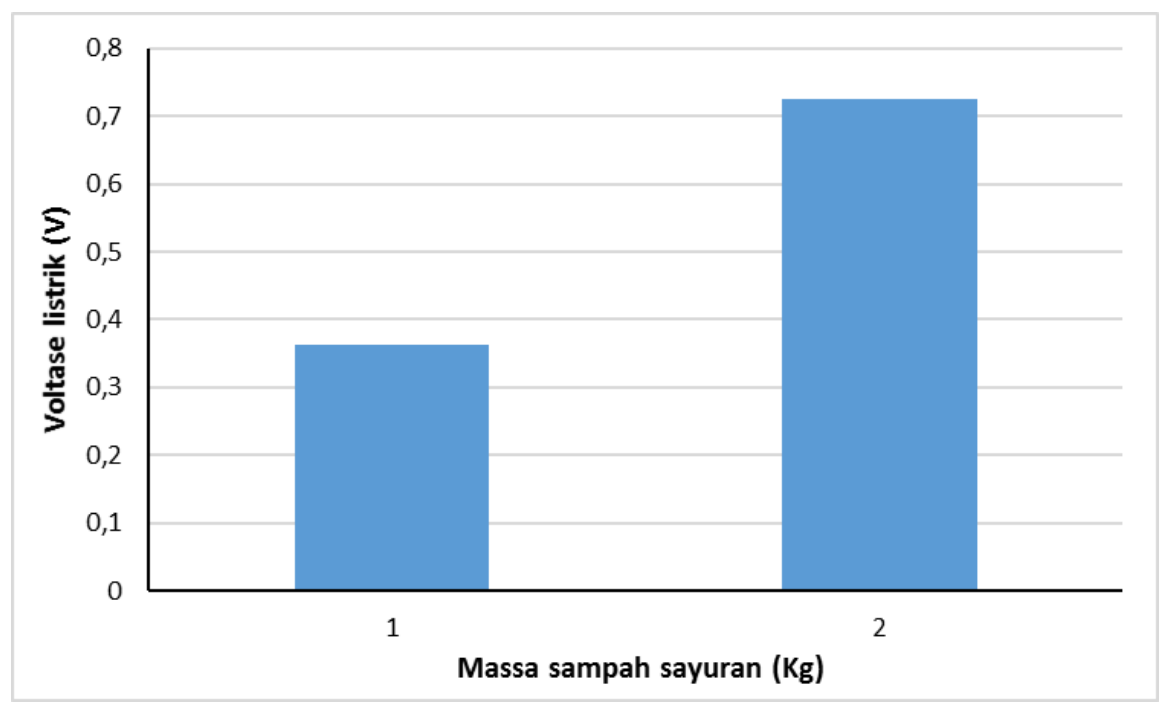

Gambar 5. Perubahan Voltase pada Masing-masing Reaktor

Kenaikan voltase pada reaktor diakibatkan meningkatnya aktivitas mikroorganisme. Logan [19] menyatakan bahwa transfer proton mempengaruhi secara signifikan pada performa MFCs. Ketika substrat yang berupa sampah sayur terdegradasi, proton diproduksi oleh anoda dan dikonsumsi oleh katoda. Dalam sistem biologik, mikroorganisme menggunakan substrat sampah sayur untuk mensintesis bahan seluler baru dan menyediakan energi untuk sintesis. Mekanismenya dapat digambarkan pada gambar dibawah ini.

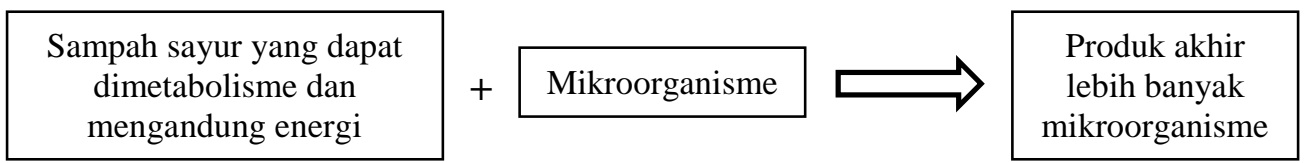

Gambar 6. Mekanisme Pertumbuhan Mikroorganisme pada Reaktor

Pada kompartemen anoda, mikroorganisme akan mengoksidasi material organik pada kondisi anaerob. Proses inilah yang berperan dalam produksi elektron atau listrik pada reaktor MFCs [20],[21]. Dengan adanya jumlah mikroorganisme yang lebih banyak, tentunya proses oksidasi akan berjalan semakin banyak. Gula sederhana sebagai molekul biodegradable terdegradasi dapat dituliskan melalui persamaan berikut:

$$
\begin{array}{llll}
\text { Anoda: } & \mathrm{C}_{\mathrm{n}}+\mathrm{H}_{2 \mathrm{n}} \mathrm{O}_{\mathrm{n}}+\mathrm{H}_{2} \mathrm{O} & \rightarrow & \mathrm{CO}_{2}+\mathrm{e}^{-}+\mathrm{H}^{+} \\
\text {Katoda: } & \mathrm{MnO}^{-}+4 \mathrm{H}^{+}+3 \mathrm{e}^{-} & \rightarrow & \mathrm{M}_{\mathrm{n}} \mathrm{O}_{2}+2 \mathrm{H}_{2} \mathrm{O}
\end{array}
$$

Elektron akan mengalir melalui sirkuit kompartemen anoda. Selanjutnya, proton akan melewati jembatan garam untuk menstabilkan muatan pada kedua kompartemen. Pada kondisi ini, terjadi perbedaan potensial antara kompartemen katoda dan anoda. Proton dan elektron yang berasal dari anoda digunakan untuk mereduksi $\mathrm{Mn}^{7+}$ menjadi $\mathrm{Mn}^{4+}$. Adanya elektron yang mengalir pada sistem tiap satuan waktu akan menghasilkan arus listrik [22].

Bila pertumbuhan mikroorganisme terhenti, mikroorganisme mati dan lisis melepaskan nutrien dari protoplasmanya untuk digunakan oleh sel-sel yang masih hidup. Dengan demikian, ketika nutrien dari sampah sayur semakin sedikit, respirasi endogenes akan berlangsung lebih banyak dan akan terjadi pengurangan padatan mikroba. Berkurangnya aktivitas mikroorganisme ini, 
menyebabkan proses oksidasi bahan organik menjadi semakin sedikit. Dengan demikian, jumlah elektron yang mengalir serta proton yang dihasilkan semakin sedikit [23].

\subsection{Pengaruh $\mathrm{pH}$ pada penurunan produksi listrik}

$\mathrm{pH}$ sangat berpengaruh terhadap pertumbuhan mikroorganisme. Pada proses pengolahan anaerob, pertumbuhan mikroorganisme lebih baik dalam suasana netral $(\mathrm{pH} 7,0)$ atau sedikit basa $(\mathrm{pH} 7,2-7,4)$, tetapi pada umumnya dapat hidup pada $\mathrm{pH}$ 6,6-7,5. Batas $\mathrm{pH}$ untuk pertumbuhan mikroorganisme merupakan suatu gambaran dari batas $\mathrm{pH}$ bagi kegiatan enzimatik [24]. Pengaruh pH pada produksi listrik ditunjukkan pada Gambar 7.

Menurunnya kondisi $\mathrm{pH}$ pada reaktor menunjukkan adanya pembentukan asam pada reaktor. Asam yang dihasilkan tersebut berasal dari bioproses pada pembusukan sampah sayuran. Materi organik partikulat dari sampah sayur seperti selulosa, hemiselulosa, pektin, lignin, akan mengalami pencairan dengan adanya enzim ekstraselular sebelum digunakan oleh bakteri asidogenik. Bakteribakteri pembentuk asam ini tumbuh dengan cepat dan menguraikan glukosa menjadi asam-asam asetat, propionat dan butirat [25].

Konversi glukosa menjadi asam asetat menghasilkan energi yang besar bagi pertumbuhan bakteri pembentuk asam. Asam asetat yang dihasilkan merupakan substrat utama bagi bakteri pembentuk metan dari asam asetat (acetoclastic methane bacteria) [13].

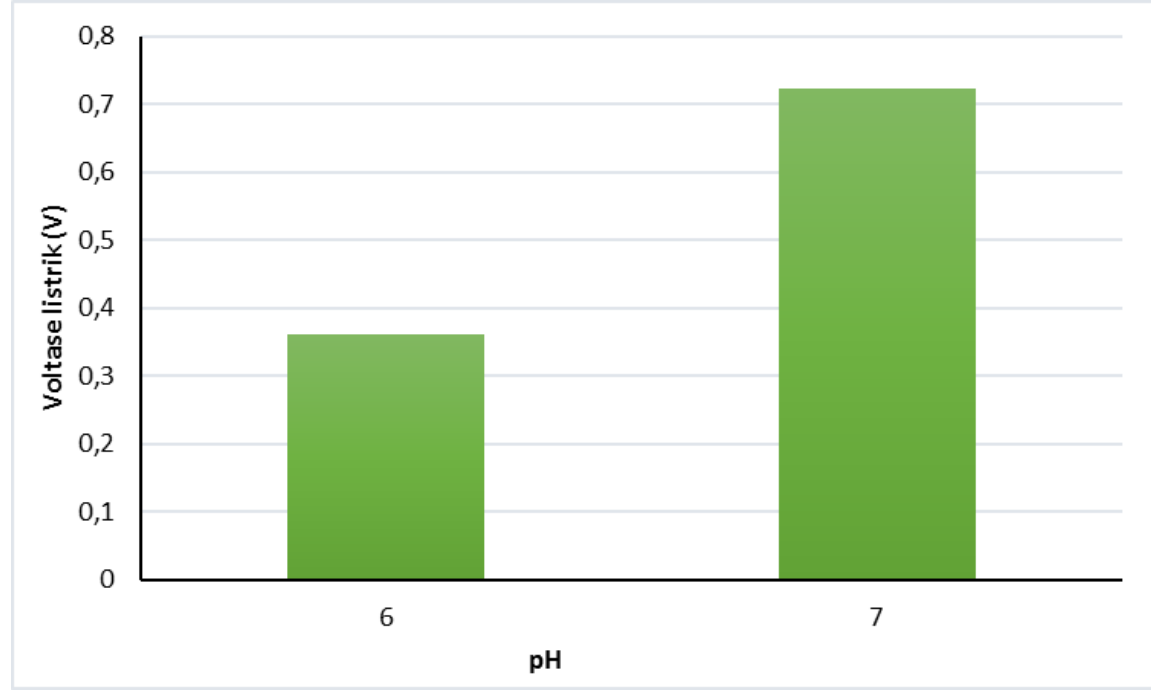

Gambar 7. Perubahan pH pada Limbah

Grafik diatas menunjukkan kisaran nilai $\mathrm{pH}$ yang terbentuk pada limbah yaitu 3,0-5,0 kemungkinan karena didominasi oleh mikroorganisme yang bersifat asidofilik yaitu mikroorganisme yang dapat tumbuh pada $\mathrm{pH}$ antara 2,0-5,0. Adanya aktivitas biologi dapat mengubah $\mathrm{pH}$ substrat. Penurunan $\mathrm{pH}$ disebabkan oleh reaksi oksidasi sulfat, nitrifikasi, oksidasi karbon organik, sedangkan kenaikan $\mathrm{pH}$ di pengaruhi oleh reaksi fotosintesis, denitrifikasi, pemecahan nitrogen organik, dan reduksi sulfat [23].

Naik turunnya $\mathrm{pH}$ ini mempengaruhi kondisi voltase pada reaktor. Hal ini dikarenakan kondisi $\mathrm{pH}$ mempengaruhi aktivitas dari mikroorganisme.

Perbandingan penggunaan air dan sampah sayur adalah 2:1. Kadar air dua kali lipat dari sampah sayur karena Keberadaan air pada reaktor MFCs berperan dalam mekanisme degradasi sampah sayur. Tingginya voltase tersebut diperkirakan menunjukkan tingginya aktivitas metabolisme dari mikroba yang ada pada sampah pasar. Kadar air yang sedikit dapat menghambat proses degradasi serta meningkatkan hambatan internal pada reaktor. 


\section{Kesimpulan}

Pengoperasian reaktor MFCs dengan variasi komposisi sampah sayur pada fase slurry menunjukkan voltase serta kerapatan daya. Dengan demikian, dapat diketahui bahwa keberadaan air pada reaktor MFCs berperan dalam mekanisme degradasi sampah sayur. Terdapat kecenderungan naiknya energi listrik yang dihasilkan pada awal pengoperasian reaktor yang menunjukkan adanya peningkatan sintesis seluler mikroorganisme. Selanjutnya, terdapat penurunan energi yang dipengaruhi $\mathrm{pH}$ lingkungan hidup mikroorganisme serta proses terbentuknya biofilm pada elektroda.

Dengan sistem Microbial Fuels Cells (MFCs), sampah sayur pasar yang berbentuk slurry dengan dilakukan penambahan EM4 dapat menhasilkan energy listrik pada 2 reaktor utama yang digunakan selama penelitian tersebut, yaitu pada Reaktor 1 tanpa penambahan EM4 (R1) adalah $700 \mathrm{mWh}$ dan pada reaktor 1 yang dilakukan penambahan EM4 (R1+) adalah $840 \mathrm{mWh}$, itu artinya slurry yang dihasilkan dari sampah sayur pasar dapat dimanfaatkan menjadi salah satu sumber energi yang terbarukan di Indonesia.

\section{Ucapan Terimakasih}

Penulis mengucapkan terimakasih kepada program studi Teknik Kimia Universitas Ahmad Dahlan atas dukungan dan fasilitas yang diberikan untuk menyelesaikan penelitian ini.

\section{Daftar Pustaka}

[1] Rahayu D, Sukmono Y (2013) Kajian Potensi Pemanfaatan Sampah Organik Pasar berdasarkan Karakteristiknya (Studi Kasus Pasar Segiri Kota Samarinda). J Sains dan Teknol Lingkung 5:77-90

[2] Djafar J, Ainun S, Dirgawati M (2014) Identifikasi Timbulan Sampah di Pasar Induk Caringin Bandung. Identifikasi Timbulan Sampah di Pasar Induk Caringin Bandung 2:1-10

[3] González D, Colón J, Gabriel D, Sánchez A (2018) The effect of the composting time on the gaseous emissions and the compost stability in a full-scale sewage sludge composting plant. Sci Total Environ 654:311-323. doi: 10.1016/j.scitotenv.2018.11.081

[4] Finnveden, G., Johansson, J., Lind, P., dan Moberg, A. (2000). Life Cycle Assessments of Energy from Solid Waste, Stockholms University, Sweden.

[5] Christy, A.D., Rismani-Yazdi, H., Carver, S., Yu, Z., Touvinen, O.H., Dehorty, B., Pashmi, N., Mullin, C. bower, T., \& Halim, W. (2008). Cellulose Conversion To Electricity in Microbial Fuel Cells: Challenges and Constrints. Departement of Food, Agricultural, and Biological Engineering. Microbial Fuel Cells First International Symposium.

[6] Kim, B.H., Chang, I.S., Gadd, G.M. (2007). Challenges In Microbial Fuel Cell Development And Operation. Applied Microbiol Biotechnol, 76(3):485-494.

[7] Ali AE-H, Gomaa OM, Fathey R, et al (2015) Optimization of double chamber microbial fuel cell for domestic wastewater treatment and electricity production. J Fuel Chem Technol 43:1092-1099. doi: $10.1016 / \mathrm{S} 1872-5813(15) 30032-3$.

[8] Zhao N, Jiang Y, Alvarado-Morales M, et al (2018) Electricity generation and microbial communities in microbial fuel cell powered by macroalgal biomass. Bioelectrochemistry 123:145-149. doi: 10.1016/j.bioelechem.2018.05.002.

[9] Feng, Y., Wang, X., Logan, B.E., Lee, H. (2008). Brewery Wastewater Treatment Using Air-Cathode Microbial Fuel Cells. Applied Microbiology and Biotechnology, 78:873-880.

[10] Abhilasha, S.M. and Sharma, V.N. (2009). Bioelectricity Production from Various Wastewater Trhrough Microbial Fuel Cell Technology. Journal of Biochemical Technology, 2(1): 133-137.

[11] Mohanakrishna G., Venkata M.S., Sarma, P.N., (2010). Bio-elechemical Treatment of Disstillery Wastewater in Microbial Fuel Cell Facilitating Decolorization and Desalination along with Power Generation, Journal of Hazardous Material, 177: 487-494.

[12] Moharir PV, Tembhurkar AR (2018) Comparative performance evaluation of novel polystyrene membrane with ultrex as Proton Exchange Membranes in Microbial Fuel Cell for bioelectricity production from food waste. Bioresour Technol 266:291-296. doi: 10.1016/j.biortech.2018.06.085. 
[13]Huang, L. \& Logan, B.E., (2008). Electrocity Generation and Treatment of Paper Recycling Wastewater Using A Microbial Fuel Cell. Applied Microbiology and Biotechnology, 80, pp 394-355.

[14] Kim, J.E., Dec, J., Bruns, M.E., \& Logan, B.E. (2008). Reductiun of Odors from Swine Wastewater by Using Microbial Fuel Cells. Applied and Environmental Microbiology, 74(8): 2540-2543.

[15] Sudigdo Sastroasmoro, 1995, Dasar-Dasar Metodologi Penelitian Klinis, Jakarta: Binarupa Aksara.

[16]Nursalam. 2003. Konsep Penerapan Metodologi Penelitian Ilmu Keperawatan, Pedoman Skripsi, Tesis Dan Instrumen Penelitian Keperawatan, Ed. 1, Jakarta: Salemba Medika.

[17] Yokoyama, H., Ohmori, H. Ishida, H. Waki, M. Tanaka, Y. 2006. Treatment of cow-waste slurry by a microbial fuel cell and the properties of the treated slurry as liquid manure, Animal Sci. J.77:634-638.

[18]Hong, S. W., Kim, H. S., \& Chung, T. H. (2010). Alteration of sediment organic matter in sediment microbial fuel cells. Environmental Pollution, 158(1), 185-191.

[19]Logan, B.E. 2007. Microbial Fuel Cells. Wiley-Interscience. ISBN 978-0-470- 23948-3.

[20] Angenent, L.T., et al. (2004). Production of Bioenergy and Biochemichals From Industrial and Agricultural Wastewater. TRENDS In Biotechnology. 22(9).

[21] Rabaey, K. \& Verstraete, W. (2005). Microbial Fuel Cells: Novel Biotechnology for Energy Generation. Trends in Biotechnology. 23(6): 291-298.

[22] Guerrero-Rangel, N., Rodriguez-de la Garza, J. A., Garza-Garcia, Y., \& Rios-Gonzalez, L. J. (2010). Comparative Study of Three Cathodic Electron Acceptors on the. International Journal of Electrical and Power Engineering, 4(1), 27-31.

[23] Jenie, B.S.L dan Rahayu, W.P. (1993). Penanganan Limbah Industri Pangan. Bogor: Kanisius.

[24] Madigan, M. T., Martinko, J.M., Stahl, D.A., Clark, D.P. (2011). Brock Biology of Microorganisms Thirteenth Edition. Benjamin Cummings: the United States of America.

[25] Bouallagui, H., Touhami, Y., Ben Cheikh, R., Hamdi, M. (2005). Bioreactor Performance In Anaerobic. 